\title{
Comparative Study Of Managements' Retention Policies And Academic Staff Turnover In Federal And State Higher Institutions In Lagos State, Nigeria, (2001 - 2010)
}

\author{
Gbenu, J. P. (Ph.D.) \\ Kolawole, 0. 0.
}

Department of Educational Management, Faculty of Education, Lagos State University, Ojo, Lagos State, Nigeiia

Lawal, R. 0.

Department of Educational Foundations and Management, School of Education, Michael Otedola College of Primary Education, Noforija-Epe, Lagos State, Nigeria Email: raslaw228@gmail.com

\section{Doi:10.5901/mjss.2014.v5n20p1813}

\begin{abstract}
The study has the purpose of determining the managements' academic staff retention policies in public higher institutions in Lagos State between 2001 and 2010 and the extent to which the same affected turnover, in particular how it affected the Federal and State higher institutions. The federal higher institutions considered are the University of Lagos, Federal College of Education and Yaba College of Technology. While the State higher institutions are the Lagos State University, Adeniran Ogunsanya College of Education and Lagos State Polytechnic. Anchored on expost-facto research design, the study population was the 3,253 academic staff as at 2010 broken down into1,960 population from Federal and 1,293 from State higher institutions. The actual sample size was 474 academic staff made up of 190 from Federal and 284 from State higher institutions Sampling was done through the simple random technique. The two instruments used for data collection were questionnaire and records from the institutions. Data were analysed using the simple percentages, means, Tables and ANOVA. Guided by two null six hypotheses, findings indicated a significant difference in managements' retention policies between Federal and State higher institutions in Lagos State and a significant difference in academic staff turnover among the academic staff structures of Federal and State higher institutions in the state. Based on these findings, recommendations were made some of which are: increase in funding to higher institutions especially State owned ones; construction of capital projects to be made a matter of policy; creation of career opportunities for academic staff; and promotion of academic staff as at when due.
\end{abstract}

Keywords: managements' retention policies; human capital development; turnover; academic staff; partial turnover; permanent turnover.

\section{Introduction}

Retaining employees remains a primary concern for many organizations generally, and specifically, for higher institutions that cherish intellectual property, considering the fact that intellectual property is a critical component of wealth creation, and indeed, a source of national development. Organizations that therefore see the human element in their affairs try to retain such human capital through various ideal management practices which expectedly are meant to discourage turnover. Beyond salary as a source of motivation, there are other factors within an organization that could strengthen workers' efforts towards improved productivity. Among these factors are the relationship between management and workers, worker-friendly policies, working environment, availability of training programmes and career opportunities and health facilities among others. These factors could be simply summed up by the phrase human capital or resource management strategies.

One can therefore conceive human capital management as that part of management concerned with people at work and their relationships within an organization. In the words of Aina (2005), "anyone who is engaged in modern organization should be concerned with human capital management to some extent". Human capital management should therefore be seen as an important management function concerned with both the careful selection and placement of new employees, the development and effective utilization of existing ones with a view to realizing the full potentials of individual employees and the goals and objectives of the organization. By implication, there must be effective human capital management strategies to encourage employees to stay with the organization. 
In human capital research and practice, employee retention or turnover, involves the issue of organization employee movement. As expressed by Zhang (2005), "research in this area by the mainstream Organizational Behaviour School has evolved to the research of factors affecting employee turnover. The positive or negative influences from these factors may either result in employee retention or turnover".

It should be pointed out that in the research on employee retention, voluntary turnover attracts attention, because employee movement such as recruitment (exterior inflow), personnel allocation, position adjustment (internal inflow), job displacement and 'disemployment' (involuntary turnover) are all controlled by the organization. However, the loss of employees who have relatively high human capital value, who choose to leave an organization, in the expression of Zhang and Zhang (2006), "can cause serious loss and difficulty, especially when turnover numbers are on the rise".

Within the sphere of academics (particularly higher institutions) in Nigeria, academic turnover commonly regarded as 'brain drain' is a serious issue with lecturers leaving for greener pastures almost on a daily basis according to available reports and pieces of evidence. In Lagos State, there are three federal and three state higher institutions, both characterised by academic staff turnover. What retention strategies are available in these classes of higher institutions? What reasons could be adduced for turnover in these institutions and at what rates are academic staff members leaving these institutions? These are fundamental questions that state the problem.

\subsection{Purpose of the Study}

The twin purpose of the study is as follows.

1. To find out if there would be any significant difference in managements' retention policies between federal and state higher institutions in Lagos State.

2. To determine if there would be any significant difference in academic staff turnover rates between federal and state higher institutions in Lagos State.

\subsection{Literature}

\subsubsection{Theoretical framework: Shaw's model}

Shaw (1999) outlines a model for developing an employee turnover and retention strategy. The model is premised on the following assumptions.

1. Turnover is rarely due to one, easily-fixed cause, and thus solutions require organizational focus and commitment.

2. Executive accountability and responsibility are critical.

3. A successful retention strategy must be built bottom-up, that is, identifying causes of voluntary turnover, reason for retention and addressing identified causes of turnover and reasons for retention.

4. Reducing undesired turnover takes time and effort - no quick fixes.

5. An on-going focus and measurement of retention/turnover is integral to sustaining low voluntary turnover levels.

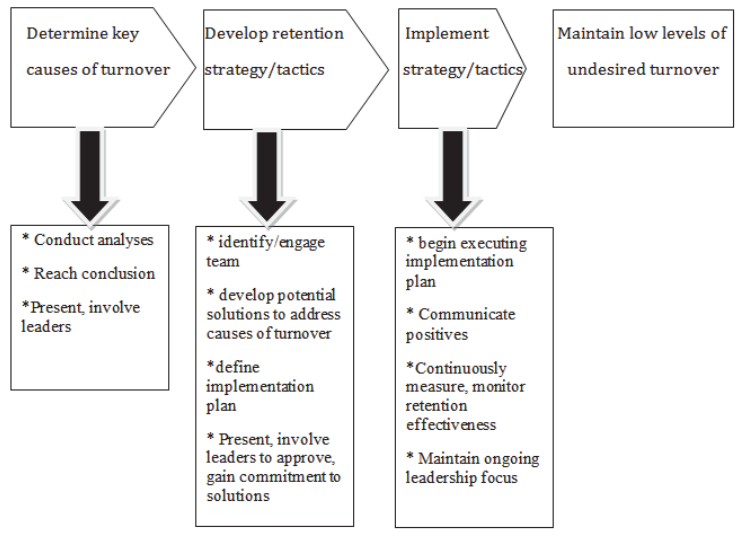

Fig. 1: Managing turnover (Shaw, 1999) 
In Shaw's (1999) explanation, the impact of turnover is manifested in increased costs, lower productivity and profitability and lower customer satisfaction. He cited recruitment and selection process, the work itself, compensation, career opportunities and the work environment, showing that the causes of turnover can be determined.

\subsubsection{The Concept of Turnover}

There are quite a number of views about the concept of turnover with variations occurring as a matter of semantics. For instance, the Bureau of Labour Statistics (2008) which defines labour turnover as "the rate at which an employer gains and loses employees, also describes it as "how long employees tend to stay or the rate of traffic through the revolving door". Staff turnover as explained by Oredein and Alao (2010) "is the voluntary or involuntary termination of an individual's employment with a given organization". Labour turnover as used by Abassi and Hollman (2000) "is the rotation of workers around the labour market, between firms, jobs and occupations, and between the states of employment and unemployment". In Woods' (2005) expression, "each time a position is voluntarily or involuntarily created, a new employee might be replaced, this replacement cycle is known as turnover".

\subsubsection{Causes of Staff Turnover (in Nigerian Higher Institutions)}

High turnover often means that employees "are unhappy with the work or compensation" according to Skabelund (2008), but it can also indicate unsafe or unhealthy conditions, or that too few employees give satisfactory performance (due to unrealistic expectations or poor candidate screening). A number of other issues such as lack of career opportunities and challenges, dissatisfaction with the job-scope or conflict with the management have also been cited as predictors of high turnover by Ruby (2002).

Low turnover indicates that none of the above is true according to Skabelund (2008): employees are satisfied, healthy and safe, and their performance is satisfactory to the employer. However the predictors of low turnover may sometimes differ from those of high turnover. Aside from the afore-mentioned according to Skabelund (2008), "salary, corporate culture, management's recognition and a comfortable workplace seem to impact employees' decision to stay with their employer".

A number of factors are responsible for employee turnover. The prospect of getting higher pay elsewhere in the expression of Cole (2009) "is one of the most obvious contributors to turnover". This practice can be regularly observed at all levels of the economic ladder, from executives and generously paid professionals in high-stress positions to entry-level workers in relatively undemanding jobs.

A negative but tight relationship between work and family is one of the factors identified as a chief cause of staff turnover. Work-family as referred to by Carmeli (2003) is explained as "an inter-role conflict in which the role pressures from work and family domains are mutually incompatible in some respect". In other words, the participation in the workfamily role is affected by participation in the family-work role. Work-family conflict is a common problem among employees described by Oredein and Alao (2010) as "an undesirable situation negatively affecting quite a number of other areas within and outside the family". Some other areas where work-family conflict manifests itself, according to Nicole (2003), include "an increase in prolong fatigue, high level of absenteeism at work, and labour turnover intentions".

Using Olabisi Onabanjo University as a case study in Nigeria, Oredein and Alao (2010) find "a statistically significant influence of work-family conflict and job satisfaction on labour turnover intentions among lecturers". Workfamily conflict according to them "is an inter-role conflict in which the role pressures from work and family domains are mutually incompatible in some respect".

Strikes by Nigerian academics as a factor at heart of causes of staff turnover also deserves mention as this situation has led to some lecturers losing faith in the structure of the educational system. Academic Staff Union of Nigerian Universities (ASUU) for instance, as reported by Ujomu (2001) has "gone on strike for several times, namely, in 1992, 1993, 1994, 1996, 1999, and 2001 to press home its demand for increased funding for the system", and still the Union is warming up for another strike as reported by Nigerian Newspapers due to the Federal government's uncooperative attitude towards the agreements made. There was a total of 18,328 academic staff to look after 433,871 students and by NUC staffing norms, a total of 33,951 should be in the system. Therefore, the academic staff shortfall was 15,718 (46\%) in the Nigerian universities in 2000 (FME, 2003).

In a related manner, the FME (2003) reports that "public universities in Nigeria remained closed for an accumulated period of about 33 months due to progressive reformulation of collective bargaining issues by university staff unions". It must also be mentioned that in 2013, ASUU went on strike for about 6 months from July 1st to press home their demands. 


\subsection{Prior Empirical Work on Human Capital Management Practices and Turnover}

Prior work has examined the determinants of both individual employees' departures and aggregate organizational turnover, according to Huselid (1995), although most of the prior work has focused on the former. For example, Arnold and Feldman (1992), Baysinger and Mobley (1993) and Cotton and Tuttle (1996) conclude that perceptions of job security, the presence of a union, compensation level, job satisfaction, organizational tenure, demographic variables such as age, gender, education and number of dependents, organizational commitment, whether a job meets an individual's expectations and the expressed intention to search for another job are all predictive of employees' leaving, and Sheridan (1992) finds that perceptions of organizational culture influence turnover. Arthur (1994) proposes that in high involvement workplaces (where human resource management practices are favourable and employee centred), "the organizational centrality of each individual employee is increased and since high involvement organizations place greater skill requirements on employees, maximum performance will demand greater levels of tenure and experience".

\subsection{Hypotheses}

The study was guided by the following null hypotheses.

1. There would be no significant difference in managements' retention policies between federal and state higher institutions in Lagos State between 2001 - 2010 inclusive

2. There would be no significant difference in staff turnover rate among the academic staff structure in federal and state higher institutions in Lagos State between 2001 - 2010 inclusive

\subsection{Methodology}

\subsubsection{Research Design}

A suitable design for the study is expost-facto.

\subsubsection{Population and Sample of the Study}

The study population was made up of the academic staff members of all the higher institutions in Lagos State in faculties, schools, institutes or departments. These institutions include University of Lagos, Akoka, Yaba; Lagos State University, Ojo; Federal College of Education (Technical), Akoka, Yaba; Adeniran Ogunsanya College of Education, Otto-ljanikin; Yaba College of Technology, Yaba, Akoka; and Lagos State Polytechnic, Isolo Campus, Isolo.

\subsubsection{Sample and Sampling Technique}

There were six components of the study population from where sample sizes were drawn. These are University of Lagos, Akoka, Yaba; Lagos State University, Ojo; Federal College of Education (Technical), Akoka, Yaba; Adeniran Ogunsanya College of Education, Otto-ljanikin; Yaba College of Technology, Yaba, Akoka; and Lagos State Polytechnic, Isolo Campus, Isolo. For each component of the study population, sample size was made up of one-third using the simple random technique. The entire six components of the study population were purposively chosen. Both population and sample sizes for each of the institutions used for the study are presented in Table 1 below. The actual sample size was 474 academic staff made up of 190 from Federal Higher Institutions and 284 from State Higher Institutions.

Table 1: Population, Planned and Actual Sample Sizes of Academic Staff Members of Tertiary Institutions in Lagos State

\begin{tabular}{|c|l|c|c|c|}
\hline S/N & Institution & $\begin{array}{c}\text { Population of } \\
\text { Academic Staff }\end{array}$ & $\begin{array}{c}\text { Planned Sample } \\
\text { Size }\end{array}$ & $\begin{array}{c}\text { Actual Sample } \\
\text { Size }\end{array}$ \\
\hline 1 & University of Lagos, Yaba & 1401 & 467 & 103 \\
\hline 2 & Lagos State University, Ojo & 880 & 293 & 180 \\
\hline 3 & Federal College of Education, Yaba & 254 & 85 & 30 \\
\hline 4 & Adeniran Ogunsanya College of Education, Otto-ljanikin & 204 & 68 & 32 \\
\hline 5 & Yaba College of Technology, Yaba & 305 & 102 & 57 \\
\hline 6 & Lagos State Polytechnic, Isolo and Ikorodu & 289 & 96 & 72 \\
\hline
\end{tabular}

Source: Institutions' Academic Planning Unit (2011) 


\subsubsection{Research Instruments}

Two major instruments were found suitable to collect data for the study: a self-constructed questionnaire tagged 'Managements' Retention Policies Questionnaire' (MRPQ) which had three sections: A, B, and C. Section A was made up of personal information on the respondents. The elements in this Section are name of institution, institution's nomenclature, institution's status, educational qualification, academic cadre, sex, year of employment into the institution as lecturer and experience as a lecturer. Section B (broken down into 5 stages - $\mathrm{B}_{1}$ - $\mathrm{B}_{5}$ ) consisted of items on institutions' pillars of retention policies. All these were encapsulated by variables such as 'management's policy fluidity $\left(B_{1}\right)$, management/staff relationship $\left(B_{2}\right)$, state of environment $\left(B_{3}\right)$, welfare structure $\left(B_{4}\right)$, and research activities $\left(B_{5}\right)$ respectively In all, there were forty-three items for section $\mathrm{B}$.

Section $C$ required respondents to state any other management retention policies adopted by their institutions under the period of review which were meant to improve productivity and retained academic staff.

The other instrument was made up of records from various institutions on turnover of staff (partial and permanent) between 2001 and 2010. Specifically, these records showed academic staff who had gone on sabbatical, leave of absence and permanently resigned due to the poor management's retention policies of the institutions from 2001 to 2010.

\subsubsection{Validity and Reliability of Instruments}

The questionnaire instrument was designed with the assistance of experts in measurement and evaluation and educational management using the purpose of the study and hypotheses as guides in constructing the items. Another index used is language clarity. By these measures, both the face and content validity of the instrument were ensured. The other instrument which served as a source of data from the institutions' records was assumed to serve the purpose for which it was meant and therefore adjudged valid. The reliability coefficient of the 'Managements' Retention Policies' instrument was established using the test-retest method. Data from the two forms of administration were correlated using the Pearson product-moment correlation giving a coefficient of 0.89 and considered high enough for final administration. The second instrument is from the institutions' staff records collected from the Academic Personnel Division Planning Units or Establishment of the Institutions. These were assumed to be valid.

\subsection{Data Analysis}

\subsubsection{Test of Hypotheses}

Hypothesis 1

There would be no significant difference in managements' retention policies between federal and state higher institutions in Lagos State between 2001 - 2010 inclusive

Table 2: Valued Elements of Managements' Retention Policies in Higher Institutions in Lagos State between 2001 and 2010 (in \%)

\begin{tabular}{|c|c|c|c|c|c|c|c|c|}
\hline & \multicolumn{8}{|c|}{ Institutions } \\
\hline & \multicolumn{4}{|c|}{ Federal } & \multicolumn{4}{|c|}{ State } \\
\hline & UNILAG & FEDCOLL & YABATECH & Mean & LASU & AOCOED & LAGOSPOLY & Mean \\
\hline \multirow{5}{*}{ 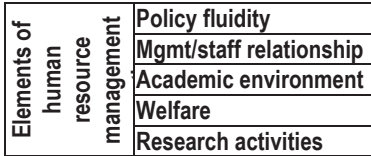 } & 68.72 & 69.9 & 67.21 & 68.61 & 66.39 & 67.87 & 72.27 & 68.84 \\
\hline & 71.97 & 68.58 & 68.95 & 69.83 & 62.4 & 69.14 & 71.88 & 67.81 \\
\hline & 55.61 & 53.24 & 65.01 & 57.96 & 54.85 & 50.78 & 55.48 & 53.70 \\
\hline & 60.68 & 66.25 & 70.29 & 65.74 & 60.23 & 60.16 & 64.67 & 61.69 \\
\hline & 68.72 & 68.65 & 74.84 & 70.74 & 60.59 & 67.38 & 68.01 & 65.33 \\
\hline \multicolumn{4}{|c|}{ Mean Average } & 66.58 & & & & 63.47 \\
\hline
\end{tabular}

Table 2 is the summary of managements' retention policies put in place by higher institutions in Lagos state namely University of Lagos (UNILAG), Lagos; Federal College of Education (FEDCOLL), Yaba; Yaba College of Technology (YABATECH), Yaba; Lagos State University (LASU), Ojo; Adeniran Ogunsanya College of Education (AOCOED), OttoIjanikin; and Lagos State Polytechnic (LAGOSPOLY), Isolo. Elements of the managements' retention policies considered by the study include policy fluidity (which shows the extent to which management is proactive to situations at hand through policy), management/staff relationship (which shows the connection between management and staff members 
through cordial relationship or otherwise), academic environment (which shows how conducive the environment is in relation to academic activities, a reflection of management's ingenuity), welfare (which shows the extent to which management is concerned about staff welfare through salary increments, bonuses, health services, leaves, etc.) and research activities (which shows how management encourages research activities among academic staff members through the provision of necessary facilities).

On a comparative note, the Federal higher institutions has a slight edge over their State counterparts going by the mean value of $66.58 \%$ possessed as against that of the state of $63.47 \%$. The issue of whether the difference is significant or not is established by the tested hypothesis 1 .

Table 3: Summary of ANOVA on Managements' Retention Policies in Federal and State Higher Institutions in Lagos State

\begin{tabular}{|l|c|c|c|c|c|c|c|}
\hline Source of Variation & Sum of Squares & $\mathrm{df}$ & Mean Squares & $F_{\text {cal }}$ & $F_{\text {tab }}$ & Sig. level & Decision \\
\cline { 1 - 4 } Between Groups & 479671.432 & 5 & 95934.286 & \multirow{2}{*}{11.994} & \multirow{2}{*}{2.21} & \multirow{2}{*}{0.05} & \multirow{2}{*}{ Reject $\mathrm{H}_{0}$} \\
\hline Within Groups & 3743209.414 & 468 & 7998.311 & & & \\
\cline { 1 - 5 } & 4222880.846 & 473 & & & \\
\hline
\end{tabular}

A significant difference was found to exist among the six institutions of higher learning in Lagos State made up of three Federal institutions (University of Lagos, Federal College of Education and Yaba College of Technology) and three State institutions (Lagos State University, Adeniran Ogunsanya College of Education and Lagos State Polytechnic) in terms of managements' retention policies put in place by management teams. This is evidenced by the $F_{c a l}>F_{\text {tab }}$ at 0.05 level of significance at the degree of freedom of $(5,468)$.

Hypothesis 2

There would be no significant difference in staff turnover rate among the academic staff structure in federal and state higher institutions in Lagos State between 2001 - 2010 inclusive

Table 4: Turnover in Higher Institutions in Lagos State in relation to Staff Strength as at 2010

\begin{tabular}{|c|c|c|c|c|c|c|c|}
\hline & \multicolumn{6}{|c|}{$\begin{array}{l}\text { Institutions } \\
\end{array}$} \\
\hline & & UNILAG & FEDCOLL & YABATECH & LASU & AOCOED & LAPOLY \\
\hline \multirow{7}{*}{ 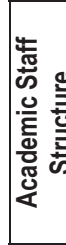 } & $\mathrm{P} / \mathrm{CL}$ & $108(9.55 \%)$ & $9(3.63 \%)$ & $5(1.75 \%)$ & $55(6.88 \%)$ & $10(5.26 \%)$ & $41(16.02 \%)$ \\
\hline & AP/PL & $58(5.13 \%)$ & $1(0.40 \%)$ & $8(2.81 \%)$ & $26(3.25 \%)$ & $5(2.63 \%)$ & $0(0 \%)$ \\
\hline & $\mathrm{SL}$ & $55(4.86 \%)$ & $0(0 \%)$ & $5(1.75 \%)$ & $44(5.5 \%)$ & $12(6.32 \%)$ & $2(0.78 \%)$ \\
\hline & $\mathrm{L}_{1}$ & $4(0.35 \%)$ & $0(0 \%)$ & $2(0.70 \%)$ & $9(1.13 \%)$ & $15(7.89 \%)$ & $3(1.17 \%)$ \\
\hline & $\mathrm{L}_{2}$ & $7(0.62 \%)$ & $5(2.02 \%)$ & $9(3.16 \%)$ & $12(1.5 \%)$ & $8(4.21 \%)$ & $4(1.56 \%)$ \\
\hline & $\mathrm{L}_{3} / \mathrm{GA}$ & $0(0 \%)$ & $1(0.40 \%)$ & $1(0.35 \%)$ & $15(1.88 \%)$ & $15(7.89 \%)$ & $2(0.78 \%)$ \\
\hline & $\mathrm{AL}$ & $0(0 \%)$ & $3(1.21 \%)$ & $1(0.35 \%)$ & $9(1.13 \%)$ & $10(5.26 \%)$ & $1(0.39 \%)$ \\
\hline & Total & $\begin{array}{c}232(20.51 \%) \\
{ }^{*} S S=1131\end{array}$ & $\begin{array}{l}19(7.66 \%) \\
{ }^{*} S S=248\end{array}$ & $\begin{array}{c}31(10.88 \%) \\
{ }^{*} \mathrm{SS}=285\end{array}$ & $\begin{array}{c}170(21.25 \%) \\
* \mathrm{SS}=800\end{array}$ & $\begin{array}{c}75(39.47 \%) \\
{ }^{*} \mathrm{SS}=190\end{array}$ & $\begin{array}{c}53(20.70 \%) \\
{ }^{*} S S=256\end{array}$ \\
\hline
\end{tabular}

*SS = Staff Strength as at 2010

Table 5: Summary of ANOVA on Turnover in Academic Staff Structures in Higher Institutions in Lagos State

\begin{tabular}{|l|c|c|c|c|c|c|c|}
\hline Source of Variation & Sum of Squares & $\mathrm{df}$ & Mean Squares & $F_{\text {cal }}$ & $F_{\text {tab }}$ & Sig. level & Decision \\
\hline Between Groups & 5201.905 & 5 & 1040.381 & \multirow{2}{*}{2.677} & \multirow{2}{*}{2.49} & \multirow{2}{*}{0.05} & \multirow{2}{*}{ Reject $\mathrm{H}_{0}$} \\
\cline { 1 - 5 } Within Groups & 13990.571 & 36 & 388.627 & & & \\
\cline { 1 - 5 } & 19192.476 & 41 & & & & \\
\hline
\end{tabular}

A significant difference was found to exist among the six institutions of higher learning in Lagos State made up of three Federal institutions (University of Lagos, Federal College of Education and Yaba College of Technology) and three State institutions (Lagos State University, Adeniran Ogunsanya College of Education and Lagos State Polytechnic) in terms of academic staff structures ranging from Professor/Chief Lecturer to Graduate Assistant/Assistant Lecturer. This is evidenced by the $F_{c a l}>F_{\text {tab }}$ at 0.05 level of significance at the degree of freedom of $(5,36)$. 


\section{Discussion}

Federal higher institutions in Lagos State made up of University of Lagos, Federal College of Education and Yaba College of Technology have a slight edge over their state counterparts made up of Lagos State University, Adeniran Ogunsanya College of Education and Lagos State Polytechnic in terms of managements' retention policies adopted by management teams of these institutions. Elements of the managements' retention policies considered by the study which were found to be present in both classes of institutions, though at varying degrees, include management's policy fluidity, management/staff relationship, academic environment, welfare and research activities.

Management policy fluidity refers to the extent to which managements of the institutions are proactive to challenges through policies which are in consonance with workers' survival or the growth of the institutions. Management/staff relationship describes the flow of relationship and communication between management and staff to produce good rapport and a stress free academic environment. The academic environment is a vital part of the success of higher institutions generally. Thus, this element shows the extent to which academic staff members are satisfied with facilities within their institutions to make their jobs of teaching, research and community services easy. Staff welfare shows how management teams show concern through prompt payments of salaries, annual increments and promotion, housing facilities, leaves among others. Research is a hallmark of the success of higher institutions. How far the managements can go to encourage research activities in higher institutions, especially the support given to academic staff members without Ph.D is a major concern to academic staff addressed by this element.

Relating managements' retention policies to turnover in these higher institutions, State higher institutions recorded higher turnover than Federal higher institutions under the period of review, which ran across all academic structures. This was attributed to the managements' policies put up by State higher institutions' management teams, which when valued, was lower than that of the Federal higher institutions.

Labour turnover or 'brain drain' as it is being referred to in higher institutions is one of the major challenges facing education in Nigeria which has been found to be more pronounced in state higher institutions. The decline of staff quality according to Okebukola (2002) "is reflected in high rates of 'brain drain', the declining numbers of professors and assistant professors within the university system and their falling levels of postgraduate preparation".

Given the fact that turnover is not ideal in higher institutions, a beginning point to addressing this ugly issue will be to identify the causes which largely can be handled by good managements' retention policies. The retention plan should be based on an analysis of why people leave according to Armstrong (2000). In his explanation, exit interviews may provide some information but "they are unreliable - people rarely give full reasons why they are leaving" in his remark. A better method according to him is to conduct attitude surveys at regular intervals. The retention plan should address each of the areas in which lack of commitment and dissatisfaction can arise.

\section{Conclusion}

Generally, turnover affects the growth and development of organizations but in particular, higher institutions of learning which are a nation's highest educational institutions and the roots of national development. Nigerian higher institutions have had to cope with a lot of pressure in the ten years considered arising from increasing turnover from these institutions. The experience was worse in state higher institutions. The net effect of this has shown itself in poor quality students who cannot only express themselves logically but also lack the rigours of academic exercises and researches and who are grossly involved in cultism. There is a positive relationship between high quality of academic staff in sufficient quantity and quality of students. If Nigeria wants to join comity of nations in all ramifications, then she must address the issue of academic staff turnover through good retention policies which must reflect on the leadership of the institutions, academic environment, and proactive policies especially in State higher institutions which are worse hit by turnover. The experience of the Asian Tigers is a good lesson for Nigeria to borrow.

\section{Recommendations}

Based on the findings, the following recommendations are made.

1. The State government has to do more in terms of making funds available to state higher institution to enable management teams provide facilities necessary for academic staff's retention, for all cadres.

2. Adequate provisions must be made for accessing Research grants and conference votes. Training programmes must be encouraged considering the fact that academic staff constitute intellectual property of Higher institutions that must be nurtured on a continual basis. 
3. Promotion of deserving academic staff should be affected without undue delays especially if such staff have met minimum standards for promotion.

4. The State government should adopt as a matter of principle or policy, the construction of capital projects annually to meet the physical projects' needs of higher institutions owned by the State. This should include housing projects.

5. Public higher institutions can learn from counterpart institutions both in the country (from private higher institutions with good records certified by the National Universities Commission) and abroad, strategies adopted to encourage staff retention and adopt same.

6. Management teams of public higher institutions should adopt always proactive retention policies based on emerging needs.

7. Management teams must recognise workers as the most paramount elements in the quest for growth and development in the institutions. In this regard, workers' views about turnover should regularly be sought and the challenges constantly addressed. It may not be associated with salaries. Showing concerns for staff welfare and actualizing the best retention policies may produce the desired results.

8. Finally, managements of higher institutions should create or encourage career opportunities for academic staff members to encourage their retention.

\section{References}

Abassi, S. M. and Hollman, K. W. (2000). Turnover: the real bottom line, public and voluntary turnover in the workplace: a comparison of companies across industries. Retrieved from www.google.com 5 August, 2007.

Aina, S. (2005). Managing the human capital in Nigeria. Ikeja: Fountain Training Consult.

Armstrong, M (2000). A handbook of personnel management practice. London: Kogan Page Ltd.

Arnold, H. J. and Feldman, D. C. (1992). A multivariate analysis of the determinants of turnover. Journal of Applied Psychology, 67(4), $350-360$.

Arthur, J. (1994). Effect of human resource systems on manufacturing performance and turnover. Academy of Management Journal, $37(4), 670-687$.

Basinger, B. D. and Mobley, W. H. (1993). Employee turnover: individual and organizational analysis. In K. Rowland and G. Ferris (Eds). Research in Personnel and Human Resources Management, Greenwich: CT: JAI Press.

Bureau of Labour Statistics (2008). Job openings and labour turnover survey. http://data.bls.gov/PDQ/servlet/SurveyOutputServelet? Retrieved 20/6/11

Carneli, P. T. (2003). Work-family balance, facilitation and enhancement and work-related outcomes. In K. Kareem, S. L. Donna and L. W. Demise (Eds). Handbook of work-family integration: research, theory and best practices. NY: Wiley.

Cole, J. (2009). E and Y create office of retention and turnover rates drop. HR Focus, 2(1), pp 2 - 4.

Cotton, J. L. and Tuttle, J. M. (1996). Employee turnover: a meta-analysis and review with implications for research. Academy of Management Review, 11(4), 55 - 70.

FME (2003). Education sector status report. Abuja: Federal Ministry of Education.

Huselid, M. A. (1995). The impact of human resource management practices on turnover, productivity and corporate financial performance. Academy of Management Journal, 38(1), 635 - 672.

Okebukola,, P. (2002). The state of university education in Nigeria. NUC, Abuja, Nigeria.

Oredein, A. O. and Alao, F. T. (2010). Work-family conflict, job satisfaction and labour turnover intention among state university lectrurers. Monograph. Ago-Iwoye: Adebisi Onabanjo University.

Ruby, A. (2002). Internal teacher turnover in urban middle school reforms. Journal of Education for Students Placed at Risks, 7(4), 379 406.

Sheridan, J. E. (1992). Organizational culture and employee retention. Academy of Management Journal, 35(1), 1036 - 1056.

Skabelund, J. (2008). I just work here. American Fitness, 26(3), 42.

Ujomu, P. O. (2001). Leadership, ethical values and consolidation of educational goals in a Nigerian university. Proceedings of the 12th general assembly of social science academy of Nigeria, $523-567$.

Woods, R. H. (2005). Managing hospitality human resources (2nd edition). Lausing, Ml: American Hotel and Management Association.

Zhang, Q. Z. (2005). The new economic socialistic. Beijing social science, 18(1), $54-75$.

Zhang, M. and Zhang, D. (2006). The new development of voluntary turnover model. Journal economic management. Abroad, 25(9), 24 $-28$. 